\title{
COVID-19 Coagulopathy: From Pathogenesis to Treatment
}

\author{
Teba Alnima $^{\mathrm{a}}$ Mark M.G. Mulder ${ }^{\mathrm{b}}$ Bas C.T. van Bussel ${ }^{\mathrm{b}, \mathrm{c}}$ Hugo ten Cate ${ }^{\mathrm{a}}$ \\ aDepartment of Internal Medicine, Vascular Medicine, Maastricht University Medical Centre, Maastricht, \\ The Netherlands; ${ }^{b}$ Department of Intensive Care Medicine, Maastricht University Medical Centre, Maastricht, \\ The Netherlands; ${ }^{c}$ Care and Public Health Research Institute (CAPHRI), Maastricht University, Maastricht, \\ The Netherlands
}

\section{Keywords}

COVID-19 $\cdot$ Coagulopathy $\cdot$ Hyperinflammation $\cdot$ Heparin

\begin{abstract}
Coronavirus disease 2019 (COVID-19) has emerged as a pandemic at the end of 2019 and continues to exert an unfavorable worldwide health impact on a large proportion of the population. A remarkable feature of COVID-19 is the precipitation of a hypercoagulable state, mainly in severe cases, leading to micro- and macrothrombosis, respiratory failure, and death. Despite the implementation of various therapeutic regimes, including anticoagulants, a large number of patients suffer from such serious complications. This review aims to describe the current knowledge on the pathophysiology of the coagulation mechanism in COVID-19. We describe the interplay between three important mediators of the disease and how this may lead to a hyperinflammatory and prothrombotic state that affects outcome, namely, the endothelium, the immune system, and the coagulation system. In line with the hypercoagulability state during COVID-19, we further review on the rare but severe vaccine-induced thrombotic thrombocytopenia. We also summarize and comment on available anticoagulant treatment options and include suggestions for some future treatment considerations for COVID-19 anticoagulation therapy.
\end{abstract}

(c) 2022 The Author(s).

Published by S. Karger AG, Basel

Karger@karger.com www.karger.com/aha

Karger $\stackrel{\text { ' }}{=}$
(C) 2022 The Author(s)

Published by S. Karger AG, Basel

This is an Open Access article licensed under the Creative Common Attribution-NonCommercial-4.0 International License (CC BY-NC) (http://www.karger.com/Services/OpenAccessLicense), applicable to the online version of the article only. Usage and distribution for commercial purposes requires written permission.

\section{Introduction}

Coronavirus disease 2019 (COVID-19) is caused by severe acute respiratory syndrome coronavirus 2 (SARSCOV-2) and may be characterized by a multisystem disease with marked hyperactivity of the immune, endothelial, and coagulation systems in severe cases $[1,2]$. While most of the infections remain mild to asymptomatic, about $20 \%$ of infected patients experience severe symptoms with high infection-fatality rates ranging from $4.87 \%$ for those aged $65-74$ years and $14.2 \%$ for those aged 75 years and older $[3,4]$. Although the most common cause of death is respiratory failure, coagulopathies are frequently seen and constitute an important cause of clinical deterioration in vital parameters that drive worse outcome.

Coagulation disorders are generally not uncommon in critical illness, like severe sepsis and acute respiratory distress disorder (ARDS). However, COVID-19-associated coagulopathy has unique features that are important to highlight in this setting. Many patients with SARS-COV-2 infection develop thromboembolic events, which are related to the coagulopathy. Sudden respiratory deterioration has been repeatedly attributed to the development of pulmonary embolism in patients with COVID-19 infections. Moreover, in very severe cases the coagulopathy may progress and remains activated over time, while

Correspondence to:

Hugo ten Cate, h.tencate@ maastrichtuniversity.nl 
mimicking only some aspects of other systemic coagulopathies like disseminated intravascular coagulation (DIC) [5]. In fact, previously unknown parts of the spectrum of coagulopathies appear to play a role in COVID19-related coagulopathy, which is, for example, driven by neutrophil and contact activation and characterized by hypofibrinolysis and heparin resistance [6-9].

The aims of this review are to evaluate the available data on coagulation mechanisms in COVID-19, to discuss some of the latest insights into the dysfunction of coagulation system and its interplay with endothelial and immune systems during the disease, as well as the available therapeutic interventions. We realize that our narrative review is not all-inclusive in this fast-evolving area of knowledge, but hopefully our synthesis of current knowledge would be clinically challenging and stimulating.

\section{Pathogenesis of SARS-COV-2 Infection}

SARS-COV-2, a new betacoronavirus causing an ongoing pandemic, has emerged as a novel human pathogen in December 2019 and is thought to originate from $\mathrm{Wu}$ han (China) [10]. It is an enveloped, positive-sense single-stranded RNA virus [11]. Coronaviruses usually do not cause severe infections in humans and typically only infect the upper respiratory tract [12]. However, three coronaviruses, which are able to infect the lower respiratory tract, succeeded this far to induce epidemics with a significant mortality: SARS-COV in 2003, Middle East Respiratory Syndrome in 2012, and SARS-COV-2 in 2019 [13-15]. SARS-COV-2 has a high index of transmission with a reproduction number of $2.2\left(R_{0}=2.2\right)$ compared to SARS-COV and Middle East Respiratory Syndrome [16].

SARS-COV-2 enters the human body mainly through respiratory droplets [15]. The virus enters the host cell using its receptor-binding domain on the spike protein, which is able to recognize the angiotensin-converting enzyme 2 (ACE2) receptor with a higher affinity than SARSCOV [17]. The ACE2 receptor is a membrane protein, which is highly expressed in the lungs, but also in other organs such as the kidneys, the heart, the liver, the testes, and the intestines. Notably, children showed a lower ACE2 gene expression in nasal and bronchial epithelial cells, which may explain in part the lower disease incidence in younger persons compared to adults [18]. The viral entry into the cells is further facilitated by transmembrane serine protease 2 (TMPRSS2) and cathepsin L to enhance engagement with the ACE2 receptor [19].
Once inside the host cell, the virus releases its RNA into the nucleus and viral replication starts. While patients are usually asymptomatic at this stage, dendritic cells, macrophages, and respiratory epithelial cells respond by secreting cytokines and chemokines to activate various inflammatory pathways. When the immune system fails to keep this response within certain boundaries, a state of hyperinflammation occurs when the disease advances in severity resulting in multi-organ failure, which precedes death [20-22]. Indeed increased levels of interleukin (IL)$1 \beta$, IL- 6 , and tumor necrosis factor- $\alpha$ have been shown to be associated with ARDS, multi-organ failure, and death [16]. Strikingly, these manifestations are also common to severe bacterial sepsis. Nevertheless, the hematological profile ofSARS-COV-2-associated coagulopathy is somewhat different from that in typical sepsis, with an evidently higher procoagulant and hypofibrinolytic phenotype in severe COVID-19 [23].

\section{Pathophysiology of COVID-19-Associated Coagulopathy}

Infection with SARS-COV-2 is highly associated with thromboembolic events. Several studies demonstrated an increased risk of thrombosis in intensive care unit (ICU)and non-ICU patients despite the use of anticoagulation. A recent meta-analysis revealed an estimated venous thromboembolism (VTE) rate of $25 \%$, with higher incidence in severe cases, such as those who are on mechanical ventilation [24]. The risk for VTE in COVID-19 compared to non-COVID-19 (other respiratory tract infections including $\mathrm{H} 1 \mathrm{~N} 1$ ) patients was $6 \%$ higher in general and the risk increased further to $16 \%$ in ICU patients when these two categories were compared [25]. Furthermore, the number of ischemic strokes' reports during COVID-19 infection is increasing [26, 27]. The exact etiology of COVID-19-induced coagulopathy is not fully understood yet, but a pathogen-induced interplay between the endothelium, the immune system, and the coagulation system appears to be a key element. Below we will highlight each of those components separately.

\section{COVID-19-Mediated Endothelialitis and Thrombosis}

In a basal state, the vascular endothelium plays a pivotal role in maintaining homeostasis by regulation of the immune system, inflammation, and vasomotor tone through several pathways $[28,29]$. The endothelium is heterogeneous throughout vascular beds and has many functions. The health of the endothelium varies between 
individuals [30]. Endothelial dysfunction has many dimensions, including those with regard to coagulation [31]. Endothelial cells control the coagulation system by providing a nonthrombogenic inner surface to keep an adequate blood flow without systemic clotting or bleeding [32]. In SARS-COV-2, viral entry starts by ACE2 expression on endothelial cells, which subsequently gets activated to participate in host defense and to promote localized inflammation. As a result, the affected endothelial cell layer becomes procoagulant and antifibrinolytic. Endothelial cell activation liberates the von Willebrand factor (vWF) and is also associated with shedding of thrombomodulin into blood. A higher concentration of these biomarkers in blood is associated with critical illness and death, suggesting that vWF and thrombomodulin related coagulation pathways are involved [33]. Damaged endothelial cells express the tissue factor (TF), which binds and activates factor VII to further initiate the clotting cascade with thrombin and clot formation at the end of the process [31]. In addition, the pro-inflammatory state facilitates further thrombus formation by impairment of the anticoagulant processes, such as those mediated by endothelial cell protein $\mathrm{C}$, thrombomodulin, and TF pathway inhibitor. Finally, fibrinolysis is inhibited during inflammation due to the release of plasminogen activator inhibitor-1 (PAI-1) from endothelial cells [32]. To add on the prothrombotic state, ADAMTS-13 may also be inactivated during sepsis causing insufficient cleavage of vWF. During a well-regulated immune response, these mechanisms help to eliminate the infection with consequently healing and return of endothelial cell layer to a homeostatic state. Severe SARS-COV-2 infection is characterized by hyperinflammation with deleterious effects on the vascular system [34]. However, heterogeneity of patients' endothelium and host-inflammatory responses to SARS-COV-2 infection would likely contribute to the differences in COVID-19 disease severity.

Postmortem examination of pulmonary vascular beds of patients with severe COVID-19 has demonstrated extensive endothelial injury, vascular thrombosis with microangiopathy, occlusion of alveolar capillaries, and signs of neo-angiogenesis [35]. Compared to influenza, capillary microthrombosis was 9 times more prevalent in COVID-19 with 2.7 times higher amount of new vessel growth [35]. An in vitro vascularized lung-on-chip model was used to study the interactions between virus infection and organoid responses, showing that the infection of underlying endothelial cells triggers clustering of endothelial cells with loss of barrier function, and induction of procoagulant features. Viral RNA positive cells also show an immune response, characterized by IL- 6 secretion. Inhibition of IL- 6 by tocilizumab reduced inflammation but did not prevent loss of barrier function. This simple model shows how the endothelium may respond to viral infection of pulmonary epithelium and becomes pro-inflammatory and procoagulant even without the involvement of immune cells [36].

\section{Immunothrombosis in COVID-19}

Inflammation is a natural first response of the immune system to tissue injury precipitated by infection or trauma. A classical self-limiting inflammatory response consists of four stages: recognition, recruitment of immune cells, elimination of the threat, and return to homeostasis [37]. While certain microbes evade the immune system, others (like virulent types of influenza) do somehow elicit inflammatory responses that may become life-threatening, sometimes named "cytokine storms" [38]. In this hyperinflammatory response, hypercytokinemia induces an inflammatory cell response, in a self-reinforcing cycle, with larger amounts of other pro-inflammatory mediators such as tumor necrosis factor- $\alpha$, IL- $1 \beta$, IL- 8 , and IL6 , resulting in hypotension, vascular leakage, multi-organ dysfunction, ARDS, and death [20,37]. The pathophysiology of COVID-19-induced hypercytokinemia is fairly similar to that of influenza, which is characterized by higher numbers of macrophages, neutrophils, and proinflammatory cytokines, with a decrease in lymphocytes, presumably due to apoptosis in the spleen and lungs [39]. Lower lymphocytes $\left(\mathrm{CD}^{+}\right.$and in particular $\mathrm{CD} 8^{+}$) have been repeatedly associated (as predictor) with worse outcome in COVID-19 [40]. An important associated finding is the existence of pulmonary microthrombi in $72 \%$ of patients at autopsy despite the use of anticoagulation [41]. Macroscopic pulmonary thrombi were detected in $34 \%$ of cases in postmortem investigation. This association between immune activation and coagulation is known as "immunothrombosis" that, in conjunction with endothelial dysfunction, has been proposed as a key mechanism of thrombus formation in severe COVID-19 infection [42].

After a stimulus has induced a physiological immune response, leucocytes are attracted to the site of injury or infection by signals from the activated endothelial cells. In particular, neutrophils play a crucial role in first line of innate defense, where they induce phagocytosis, degranulation, and formation of neutrophil extracellular traps (NETs) [43]. NETosis is a form of immune defense by which regulated neutrophil death induces trap formation that captures microbes and thus prevents further dissem- 
ination [43]. Notably, aged neutrophils are more prone to NETosis acting rapidly at the site of infection [44]. NETs interact with the complement and coagulation systems and inhibit fibrinolysis. The amount of NET-formation is species- and stimulus-dependent $[45,46]$. NETs also facilitate fibrin polymerization, vWF binding, platelet adhesion, and erythrocyte entrapment [47]. In addition, NETs present coagulation factors and other molecules that inhibit natural anticoagulants to further promote a prothrombotic environment $[48,49]$. To counterbalance the process of NETosis and its prothrombotic and pro-inflammatory actions, NETs have the ability to downregulate their activity, but this process is heterogeneous and may be defective under certain circumstances such as an environment with hyperinflammatory stimuli [43]. Neutrophils also contribute to thrombosis by interacting with platelets and endothelial cells. In addition, monocytes are able to express the TF on their surface whenever they are triggered [50]. Platelet chemokines like CXCL4 and CXCL7 act as neutrophil chemoattractants and CXCL4 has been shown to be involved in formation of NETs in pulmonary infection [51, 52]. In a study by Zuo et al. [53], a higher level of NETs was demonstrated in plasma of COVID-19 patients compared to control plasma, driving hyperinflammation, microvascular thrombosis, and ARDS. Even sera from patients with COVID-19 triggered NETs formation from control neutrophils, demonstrating a high virulence of the virus. Immunothrombosis is further amplified by complement activation, triggered in conjunction with neutrophil activation and recruitment of the contact system of coagulation. Here, factor XIIa triggers the production of bradykinin and kallikrein, both important immune mediators and additional triggers of the intrinsic coagulation system $[9,54,55]$. Interestingly, factor XIIa can initiate the classical complement pathway by activation of $\mathrm{C} 1$ complex, while further thrombin generation is triggered by the intrinsic coagulation cascade. The $\mathrm{C} 1$ esterase inhibitor acts as an important inhibitor for both contact activation and complement pathways. In a large cohort of COVID-19 patients, Busch et al. [9] showed that hypercoagulability and thrombotic events are driven by NETosis, contact activation, and complement, where they found increased levels of plasma complexes of kallikrein:C1 esterase inhibitor, FXIa:antithrombin, and FIXa:antithrombin despite treatment with heparins. Unrestrained activation of complement system, which has been suggested in prolonged SARS-COV-2 infection, can be detrimental by causing excessive tissue damage. Some patients with COVID-19 showed significant deposits of C5b-9 (membrane attack complex), C4d, and mannose-

Coagulation Issues in COVID-19 binding lectin-associated serine protease 2 (MASP-2) in microvasculature of several organs, indicating sustained systemic activation of lectin-complement pathway [56]. Taken together, immunothrombosis is driven by interactions between NETosis, contact activation, complement, but also the endothelium and coagulation system, all within a hyperinflammatory environment in COVID-19. Shown in Figure 1 is a simplified illustration of the pathogenesis of COVID-19-associated coagulopathy with the interplay between endothelial, immune, and coagulations systems.

\section{The Coagulation System in COVID-19: Role of}

Platelets and Fibrinolytic Enzymes

The complex and re-enforcing interactions between endothelial, immune, and coagulation systems is crucial in the devastating thrombotic consequences of severe SARS-COV-2 infection. Thus far, we highlighted the main theories behind the activation of secondary hemostasis during severe COVID-19, while primary hemostasis is also affected. Following endothelial damage, platelets are recruited to promote further inflammation and thrombosis through several signaling pathways, resulting in release of IL-1 $\beta$ and IL-18 [57]. In COVID-19, the platelets are triggered toward a hyperimmune response, which was marked by an increase in platelet-monocyte and platelet-neutrophil aggregates, associated with increased platelet activity, TF activity, and NETosis [58]. Furthermore, platelet factor 4 (PF4), known for its key role in heparin-induced thrombocytopenia (HIT), is also released from platelets in COVID-19 patients and binds to the surface of pathogens and undergoes conformational changes to bind antibodies [50,59]. Importantly, those PF4-bound pathogens and antibodies further activate other platelets and consequently amplify the process of platelet aggregation and thrombosis. This mechanism is previously described in sepsis, but also appears to play a role in COVID-19 [60, 61]. Furthermore, vWF is often increased during inflammation as a sign of endothelial activation, which was also demonstrated in COVID-19 to be associated with disease severity and mortality [33].

The fibrinolytic system is an underexposed topic. Nevertheless, it has a unique role as it is not only essential to physiological hemostasis, but it can also contribute to inflammation through cytokine induction and complement activation [62]. Plasminogen can be activated by components of the complement system, and conversely, plasminogen can act as a complement inhibitor by its lysine residues. Coronavirus infections are associated with a specific fibrinolytic profile. Patients infected with an-

Acta Haematol 2022;145:282-296 


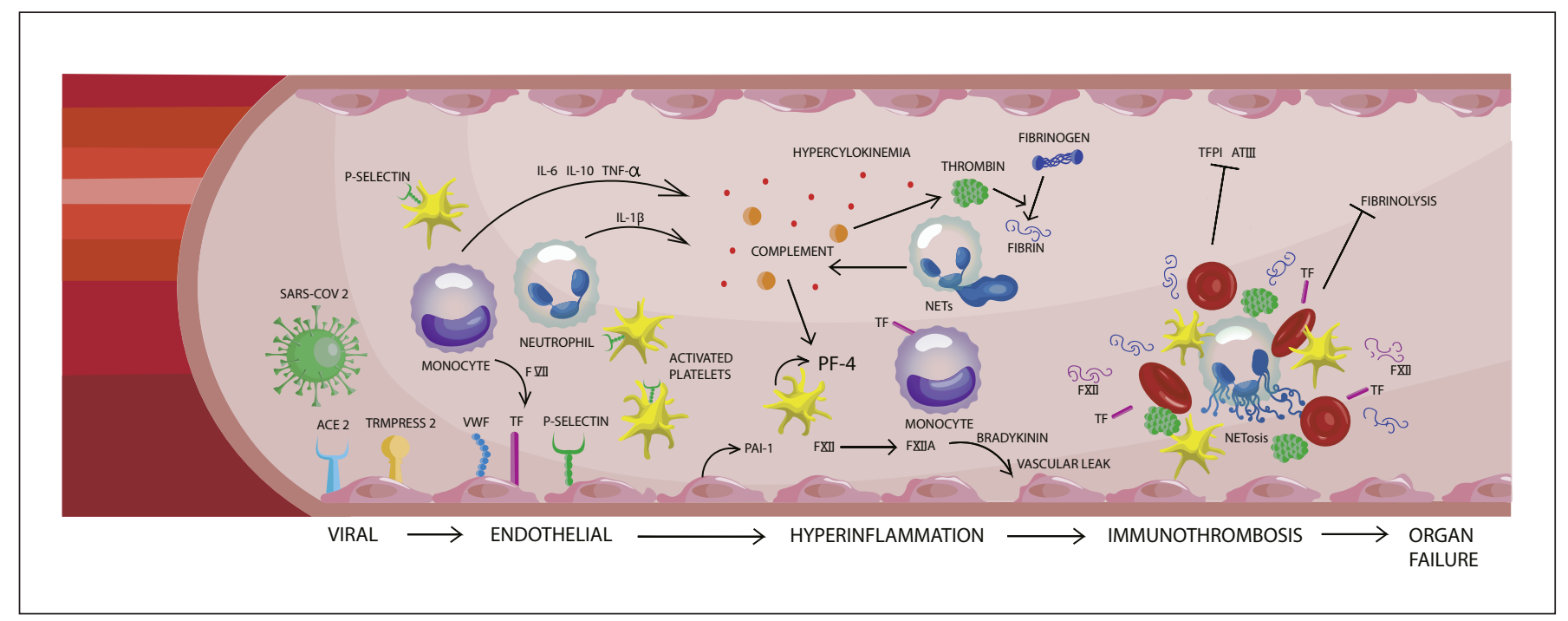

Fig. 1. Schematic illustration of the pathophysiology of COVID-19 coagulopathy and the interplay between endothelial, immune, and coagulation systems. VWF, von Willebrand factor; TF, tissue factor; PAI-1, plasminogen activator inhibitor 1; PF-4, platelet factor 4; TFPI, tissue factor pathway inhibitor; AT III, antithrombin III; TNF- $\alpha$, tumor necrosis factor- $\alpha$.

other SARS virus (i.e., SARS-COV-1) showed higher concentrations of tissue-type plasminogen activator (tPA) than healthy controls, which may promote endothelial injury and subsequently release of plasminogen activators [63]. Another study reported recently on the existence of annexin A2 antibodies in COVID-19 [64]. Annexin A2 is a plasminogen receptor localized on many types of cells and its expression increases during inflammation. It acts as a co-receptor to accelerate plasmin generation by $>60$-fold [50]. Blockage of annexin A2 by SARS-COV-2-induced antibodies may probably dampen fibrinolysis and add to the prothrombotic state in COVID-19.

\section{Vaccine-Induced Thrombotic Thrombocytopenia}

In line with the hyperinflammatory and hypercoagulable state during severe SARS-COV-2 infections, we like to take a side step toward an exceptional, but severe vaccine-induced thrombotic thrombocytopenia (VITT) [65]. Vaccination against SARS-COV-2 has been shown as to be the most important measure to limit the infectious burden of COVID-19 [66]. However, development of rare immune thrombotic thrombocytopenia has been reported several times after vaccination with adenovirusbased SARS-COV-2 vaccines (ChAdOx1 nCov-19; AstraZeneca and Ad26COV2.S, Janssen, Johnson \& John- son) [67]. Thus far, no official cases of VITT have been published after vaccination by Pfizer-BioNTech, but one probable VITT case has been reported after Moderna vaccination [68]. The incidence of VITT was estimated as 1 per 100,000 exposures [69]. Approximately $40 \%$ of those cases died of ischemic brain injury, secondary hemorrhage, or both [69]. There is an association between risk of VITT and younger age. Median age at diagnosis of VITT was 48 years in the UK VITT case series, with $85 \%$ of patients younger than 60 years [70]. Neither sex preponderance was noted ( $54 \%$ was female), nor an association with certain medical conditions was observed. $\mathrm{Nev}$ ertheless, several countries do not recommend or offer adenovirus-based vaccinations anymore. The clinical features of the vaccine-induced phenomenon consisted of severe thrombocytopenia, aggressive thrombosis, and DIC, which resembles the coagulopathy seen in patients with HIT [71]. The associated thrombotic events consisted primarily of cerebral venous thrombosis, but also arterial thrombosis and VTE. HIT is mediated by IgG autoantibodies that recognize PF4 and heparin complexes. Five to 10 days after heparin exposure, these heparin/ PF4/antibody immune complexes lead to platelet activation and the release of procoagulant factors. Platelet activation is not the only driver of the thrombotic process in HIT as more evidence appears demonstrating a crucial role of NETs in HIT-induced thrombosis [72]. Activated platelets as well as HIT-immune complexes are able to 


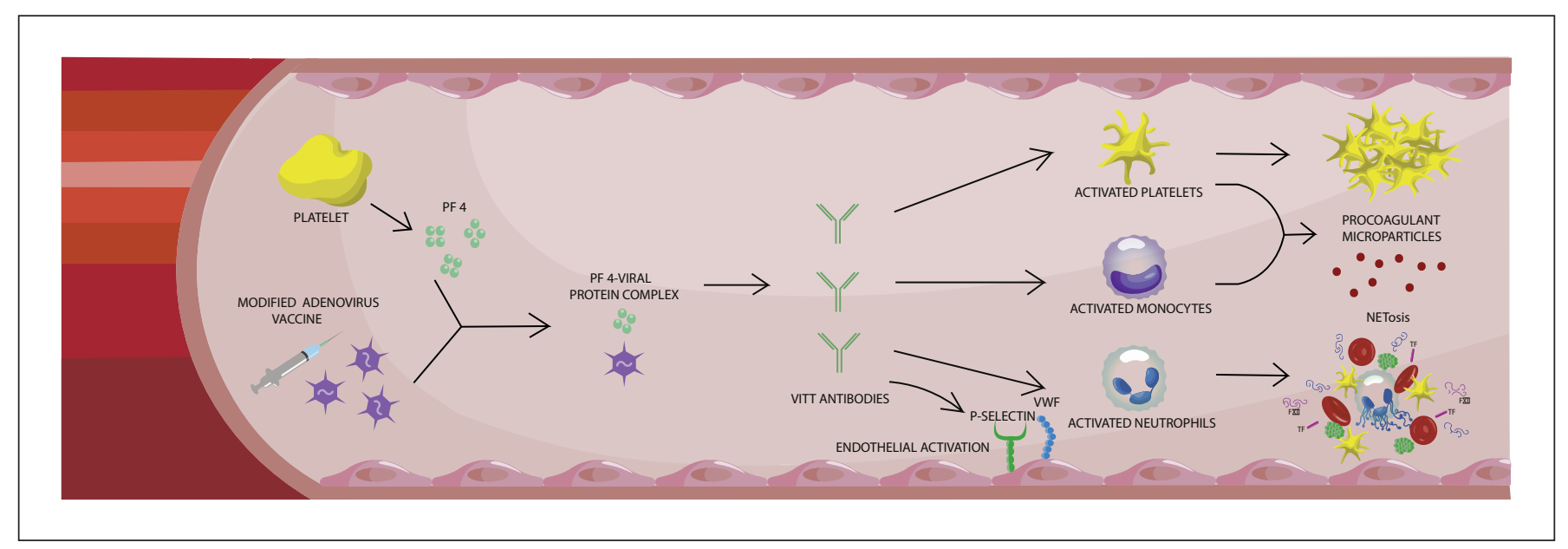

Fig. 2. Schematic illustration of the pathophysiology of VITT. PF 4, platelet factor 4; VITT, vaccine-induced thrombotic thrombocytopenia; VWF, von Willebrand factor; TF, tissue factor.

trigger NETosis, which in turn promotes thrombin generation. Nevertheless, only a small subset of patients with heparin/PF4 antibodies develop thrombocytopenia and thrombosis eventually. Inflammation and tissue trauma are the main risk factors for developing HIT, but full insight into the driving factors behind HIT is yet to be elucidated. As shown in Figure 2, VITT mimics autoimmune HIT, except from exposure to heparin. A recent study by Greinacher et al. [73] suggested that VITT is generated by a 2-step mechanism. First, PF4 interacts with vaccine components (including adenovirus hexon protein) to generate neoantigens. Second, anti-PF4 antibodies induce platelet and granulocyte activation 5-20 days after vaccination, driving release of NETs that induce immunothrombotic pathways that may lead to clinical complications. Alternatively, endogenous glycosaminoglycans present in the endothelial glycocalyx, resembling exogenous heparins, may play a role in the aberrant immune response in VITT cases. Damage to the glycocalyx may release fragmented forms of glycosaminoglycans that trigger an immune response upon electrostatic interactions with PF4 [74].

Platelet count and D-dimer levels are the most important laboratory screening tools. The diagnosis of HIT is confirmed by the presence of anti-PF4 antibodies. The diagnosis of VITT must be confirmed by PF4 ELISA as the sensitive assays used to screen for HIT are not validated to rule in the diagnosis [75]. Limited data are available on the treatment of VITT. Given the parallels with HIT, preferred treatment options for VITT consist thus far of nonheparin anticoagulants (DOACs, argatroban), the heparinoid danaparoid that is also registered for use in HIT, in combination with immune suppressive, or modulating measures like glucocorticosteroids, intravenous immunoglobulins, and plasmapheresis [69]. Future work should provide more insight into the trigger of development of anti-PF4 antibodies, risk of VITT for each SARS-COV-2 vaccine, and ideal treatment option.

\section{Assessment of Coagulation in COVID-19}

The initial evaluation of coagulopathy in patients with COVID-19 involves mostly conventional, routine, coagulations assays including clotting tests and D-dimer analysis, with hematology screening such as platelet count. The majority of patients with severe COVID-19 showed persistently elevated D-dimer levels, which were associated with disease severity [76]. D-dimer is a breakdown product of fibrin and is used as a marker of coagulation and fibrinolysis. High fibrinogen and factor VIII levels most likely explain a normal or mildly prolonged prothrombin time and a normal partial thromboplastin time in most patients with COVID-19 [77, 78]. Coagulation factors are usually within the normal range during $\mathrm{CO}$ VID-19, but the mean concentrations of fibrinogen in plasma and factor VIII are strikingly increased [78]. Natural anticoagulants, protein $\mathrm{C}$ and antithrombin, are mildly reduced [78]. In the majority of cases, there is no clinically relevant decline in platelet count and only in very severe cases of COVID-19, thrombocytopenia is observed [79]. Therefore, the classic diagnosis of DIC is not 
often present [80]. This does not rule out an important role for platelets in COVID-19. Activated platelets have been demonstrated by enhanced expression of P-selectin, a protein which is expressed following platelet activation to ensure leucocyte activation, which appeared to be higher in COVID-19 than in control groups [79]. Studies analyzing platelet aggregation by different assays are inconclusive and need further evaluation [81, 82]. Soluble markers that may reflect platelet activation show severitydependent elevations for soluble P-selectin $[83,84]$. Interestingly, hyperreactive platelets were detected in all severely ill COVID-19 patients in one study with markedly elevated agonist-induced ADP release by platelets as well as increased plasma levels of P-selectin, PF4, and thrombopoietin [85]. As most patients maintain fairly high platelet counts during admission, hyperreactivity and potential clearance from annexin positive platelets may be compensated by high bone marrow platelet production, or production and liberation from other sources including the lungs [86].

The combination of elevated D-dimer, thrombocytopenia, and prolonged coagulation times (mainly prothrombin time) resembles the abnormalities commonly seen in DIC, which is defined as an acquired syndrome characterized by activation of coagulation system, resulting in formation of intravascular thrombi and, depletion of platelets and coagulation factors, leading to vascular obstruction/ischemia and multi-organ failure [87]. Yet, COVID-19 coagulopathy cannot be seen as a typical DIC for the following reasons; thrombocytopenia is not as severe as in sepsis-associated DIC, clotting factors are usually in the normal range, and physiological anticoagulants (protein $\mathrm{C}$ and antithrombin) are not evidently depleted as in sepsis-associated DIC (see Table 1) [88].

More sophisticated integral coagulation tests including the thrombin generation assay, an increasingly recognized tool to evaluate the hemostatic system in plateletpoor plasma, are also utilized to assess COVID-19 coagulopathy $[89,90]$. Limited knowledge is available on its use and findings in COVID-19 infection, but some reports indicated high thrombin generation in SARS-COV-2 pneumonia despite the use of anticoagulation [91, 92]. Specific applications of thrombin generation assay may facilitate better documentation of anticoagulant efficacy, but this needs clinical verification [93]. An important observation was done with viscoelastic testing by rotational thromboelastometry. In patients with COVID-19, rotational thromboelastometry demonstrated a hypercoagulable state marked by increased clot mechanical strength and impaired fibrinolysis $[94,95]$. This profound clot for-
Table 1. Characteristic biomarkers for COVID-19 coagulopathy versus DIC

\begin{tabular}{lll}
\hline & COVID-19 coagulopathy & DIC \\
\hline Platelets & Normal to $\downarrow$ & $\downarrow$ \\
D-dimer & $\uparrow$ & $\uparrow$ \\
PT/aPTT & Normal to $\uparrow$ & $\uparrow$ \\
Fibrinogen & $\uparrow$ & Normal to $\downarrow$ \\
AT III & Normal to $\downarrow$ & $\downarrow$ \\
\hline
\end{tabular}

PT, prothrombin time; aPTT, activated partial thromboplastin time; DIC, diffuse intravasal coagulation; AT III, antithrombin III.

Table 2. Characteristic biomarkers for COVID-19 coagulopathy

\begin{tabular}{ll}
\hline Biomarker & Common finding in severe COVID-19 \\
\hline Platelets & Normal to $\downarrow$ \\
PT & Normal to $\uparrow$ \\
aPTT & Normal \\
D-dimer & $\uparrow \uparrow$ \\
Fibrinogen & $\uparrow *$ \\
Factor VIII & $\uparrow$ \\
VWF & $\uparrow$ \\
Protein C & $\downarrow$ \\
Antithrombin & $\downarrow$ \\
TGA & Hypercoagulable \\
ROTEM & Hypercoagulable and hypofibrinolytic \\
PAI & $\uparrow$
\end{tabular}

PT, prothrombin time; aPTT, activated partial thromboplastin time; TGA, thrombin generation assay; ROTEM, rotational thromboelastometry. ${ }^{*}$ Fibrinogen is usually increased, except in cases with DIC.

mation and resistance to lysis persisted in consecutive blood samples from ICU patients with COVID-19 but normalized in survivors at 6 months post-discharge [5, 96]. Collective data on viscoelastic testing and fibrinolysis were recently reviewed elsewhere [95]. The fibrinolytic shutdown in COVID-19 has been proposed as another important mechanism favoring persistent (immuno) thrombosis [97]. Molecular players contributing to impaired fibrinolysis include elevated levels of plasminogen activator inhibitors (PAI)- 1 and -2 and TAFI, coupled to resistance of clot lysis to the addition of $\mathrm{PAA}$ or urokinase, which is associated with disease severity [98]. Whether recombinant tPA is a therapeutic option in COVID-19 warrants further investigation. Table 2 summarizes the current biomarkers of coagulopathy in COVID-19. Novel biomarkers are being studied and will be introduced in the near future. 


\section{Challenges with Current Antithrombotic Treatment}

Identification and quantification of the hyperinflammatory and hypercoagulable state in COVID-19 and other highly pathogenic respiratory infections represent prospective targets for modulation of host immune responses and coagulation system. Like we have mentioned before, pulmonary inflammation, endothelial injury, and microvascular thrombosis probably act in concert to result in ARDS, which is the most common cause of death in patients with COVID-19. Several studies suggested that heparin decreases the risk of disease severity and death [99-101]. Heparins or low molecular weight heparins (LMWHs) possess next to anticoagulant properties additional anti-inflammatory and antiviral actions [102]. Heparin belongs to the glycosaminoglycans family and its polyanionic nature allows to bind to other structures such as antithrombin, cytokines, chemokines, cytotoxic peptides, and complement proteins that are involved in inflammation. In addition, heparin may reduce P-selectin expression resulting in reduced adhesion of leucocytes to endothelial cells [43]. Several studies demonstrated that LMWH reduces the release and may neutralize the biological actions of IL-6 and IL-8 [43, 102]. Finally, recent experiments revealed that human coronaviruses use heparin sulfate for attachment to target cells and that upon binding, the virus undergoes a structural modulation, which prevents further infection [103]. Thus, it seemed that heparin would provide a valuable therapeutic means of counteracting the virus-induced immunothrombosis in COVID-19. Nevertheless, despite adequate thromboprophylaxis in COVID-19 patients, $4.4 \%$ showed symptomatic VTE, $2.5 \%$ ischemic stroke, and $1.1 \%$ myocardial infarction [104]. The overall prevalence of thrombotic complications ranged from $2.6 \%$ in noncritical patients to $35.3 \%$ in critically-ill patients [104]. This means that heparin alone or in the current dosage is not sufficient and that other anticoagulants and/or other concomitant therapies are required to tackle the hypercoagulable state in COVID-19.

\section{Prophylactic versus Therapeutic LMWH for Thrombosis Prevention}

Bearing in mind the regularly observed heparin resistance in COVID-19 patients, it is reasonable to speculate that increasing the dose of heparin should reduce the rate of VTE [105]. Earlier published randomized trials have suggested that therapeutic heparin is beneficial for moderately ill COVID-19 patients, while it is of no benefit in critically ill patients $[106,107]$. Critical illness was de- fined as the need of ICU-level of respiratory or cardiovascular organ support including high-flow nasal cannula (HFNC) oxygen treatment. In addition, data were statistically analyzed using the Bayesian cumulative logistic model. The investigators attributed the lack of benefit of therapeutic anticoagulation in critical illness to the fact that patients in ICU may have reached "a point-ofno-return" with irreversible damage and organ failure. The observed higher probability of survival and reduced ICU-level organ support by initial administration of therapeutic heparin in moderately ill patients may be due to earlier interruption or reduction of the immunothrombotic process triggered by SARS-COV-2. However, there are still some important issues regarding the performed studies. First, the definition of severe or critical illness is quite comprehensive. A little over $30 \%$ of critically ill COVID-19 patients were included based on the need of HFNC oxygen treatment. The question arises as what were the criteria to include those patients and how "critical" their health condition was. In our experience, the indication of starting HFNC is variable and depends on the judgment of medical teams which may differ between and within medical centers [108]. This may bring a bias between groups and disease severity within each treatment group. Second, no information was provided on imaging of the lungs at the moment of inclusion, which leaves us wondering if extensive pulmonary damage or "disease severity" is associated with the primary outcome of therapeutic versus prophylactic LMWH and survival. In addition, we noticed that the value of $\mathrm{D}$-dimer in the critically ill COVID-19 groups was not extremely high as we would expect from ICU patients. More importantly, no anti-Xa levels and antithrombin levels were available to control the effect of therapy as severe inflammatory states are known to markedly reduce the level and impair the function of antithrombin [109]. Third, although the Bayesian approach has several advantages, one important pitfall is the requirement of a prior distribution, which is often difficult to formulate and may depend on individual conclusions at a certain point of time. Finally, it is remarkable that only about $2 \%$ of the participants in the critical COVID-19 patients received tocilizumab. This percentage is even lower in the noncritical COVID-19 patient groups. Nowadays, tocilizumab has gained its place as standard of care treatment in those with high inflammation parameters and oxygen support. Administration of tocilizumab to those patients was beneficial in earlier studies [110] and may hypothetically reduce or even eliminate the suggested need for therapeutic anticoagulation in earlier disease stages by reducing 
Table 3. Summary of the effect of different anticoagulant treatment options during COVID-19 infection from large trials

\begin{tabular}{|c|c|c|c|c|c|c|c|c|}
\hline Author & Trial & Journal & Design & Population & $N$ & Intervention & Outcome & Main findings \\
\hline $\begin{array}{l}\text { Spyropoulos } \\
\text { et al. [111] }\end{array}$ & $\begin{array}{l}\text { The HEP-COVID } \\
\text { randomized } \\
\text { clinical trial }\end{array}$ & $\begin{array}{l}\text { JAMA Intern } \\
\text { Med, } 2021\end{array}$ & MCRCT & $\begin{array}{l}\text { Non-ICU and } \\
\text { ICU }\end{array}$ & 253 & $\begin{array}{l}\text { Standard } \\
\text { prophylactic- or } \\
\text { intermediate- } \\
\text { dose LMWH or } \\
\text { UFH versus } \\
\text { therapeutic- } \\
\text { dose enoxaparin }\end{array}$ & $\begin{array}{l}\text { VTE, ATE, death, } \\
\text { major bleeding, } \\
\text { at } 30 \text { days }\end{array}$ & $\begin{array}{l}\text { Reduced VTE, ATE, and } \\
\text { death in non-ICU treatment } \\
\text { group } \\
\text { No treatment effects in ICU } \\
\text { population } \\
\text { No differences in major } \\
\text { bleeding between groups }\end{array}$ \\
\hline $\begin{array}{l}\text { Perepu et al. } \\
\text { [112] }\end{array}$ & & $\begin{array}{l}\text { J Thromb } \\
\text { Haemost, } \\
2021\end{array}$ & MCRCT & $\begin{array}{l}\text { ICU and/or } \\
\text { ISTH overt DIC } \\
\text { score } \geq 3\end{array}$ & 176 & $\begin{array}{l}\text { Standard } \\
\text { prophylactic- } \\
\text { dose versus } \\
\text { intermediate- } \\
\text { dose enoxaparin }\end{array}$ & $\begin{array}{l}\text { Death, VTE, ATE, } \\
\text { major bleeding, } \\
\text { at } 30 \text { days }\end{array}$ & $\begin{array}{l}\text { No treatment effects were } \\
\text { observed } \\
\text { No differences in major } \\
\text { bleeding between groups }\end{array}$ \\
\hline $\begin{array}{l}\text { Lopes et al. } \\
\text { [113] }\end{array}$ & $\begin{array}{l}\text { The ACTION } \\
\text { randomized } \\
\text { clinical trial }\end{array}$ & Lancet, 2021 & MCRCT & $\begin{array}{l}\text { Predominately } \\
\text { hospitalized } \\
\text { clinically stable }\end{array}$ & 615 & $\begin{array}{l}\text { Standard } \\
\text { prophylactic- } \\
\text { dose enoxaparin } \\
\text { or UFH versus } \\
\text { therapeutic- } \\
\text { dose } \\
\text { rivaroxaban or } \\
\text { enoxaparin or } \\
\text { UFH }\end{array}$ & $\begin{array}{l}\text { Time to death, } \\
\text { duration of } \\
\text { hospitalization, } \\
\text { duration of } \\
\text { supplemental } \\
\text { oxygen, at } 30 \\
\text { days }\end{array}$ & $\begin{array}{l}\text { No treatment effects were } \\
\text { observed } \\
\text { Significantly increased } \\
\text { number of bleeding } \\
\text { complications in the } \\
\text { treatment group }\end{array}$ \\
\hline $\begin{array}{l}\text { Sadeghipour } \\
\text { et al. [114] }\end{array}$ & $\begin{array}{l}\text { The INSPIRATION } \\
\text { randomized } \\
\text { clinical trial }\end{array}$ & JAMA, 2021 & MCRCT & $\mathrm{ICU}$ & 562 & $\begin{array}{l}\text { Standard } \\
\text { prophylactic- } \\
\text { dose versus } \\
\text { intermediate- } \\
\text { dose enoxaparin }\end{array}$ & $\begin{array}{l}\text { VTE, ATE, ECMO, } \\
\text { death, at } 30 \text { days }\end{array}$ & $\begin{array}{l}\text { No treatment effects were } \\
\text { observed } \\
\text { No differences in major } \\
\text { bleeding between groups }\end{array}$ \\
\hline $\begin{array}{l}\text { Sholzberg } \\
\text { et al. [131] }\end{array}$ & $\begin{array}{l}\text { The RAPID } \\
\text { randomized } \\
\text { clinical trial }\end{array}$ & BMJ, 2021 & MCRCT & $\begin{array}{l}\text { Moderately ill } \\
\text { hospitalized }\end{array}$ & 465 & $\begin{array}{l}\text { Standard } \\
\text { prophylactic- } \\
\text { dose versus } \\
\text { therapeutic- } \\
\text { dose heparin }\end{array}$ & $\begin{array}{l}\text { Death, invasive } \\
\text { or noninvasive } \\
\text { mechanical } \\
\text { ventilation, ICU } \\
\text { admission, at } 28 \\
\text { days }\end{array}$ & $\begin{array}{l}\text { No treatment effects were } \\
\text { observed } \\
\text { No differences in major } \\
\text { bleeding between groups }\end{array}$ \\
\hline $\begin{array}{l}\text { Lawler and } \\
\text { colleagues } \\
{[106]}\end{array}$ & $\begin{array}{l}\text { The ATTACC, } \\
\text { ACTIV-4a, and } \\
\text { REMAP-CAP, } \\
\text { multiplatform } \\
\text { randomized } \\
\text { clinical trial }\end{array}$ & $\begin{array}{l}\text { N Engl J } \\
\text { Med, } 2021\end{array}$ & MPRCT & Noncritically ill & 2244 & $\begin{array}{l}\text { Standard } \\
\text { prophylactic- } \\
\text { dose versus } \\
\text { therapeutic- } \\
\text { dose heparin }\end{array}$ & $\begin{array}{l}\text { Organ support- } \\
\text { free days, death, } \\
\text { at } 21 \text { days }\end{array}$ & $\begin{array}{l}\text { Increased probability of } \\
\text { survival to hospital } \\
\text { discharge with reduced } \\
\text { organ support in the } \\
\text { treatment group } \\
\text { Major bleeding occurred } \\
\text { more frequently in the } \\
\text { treatment group }\end{array}$ \\
\hline $\begin{array}{l}\text { Goligher and } \\
\text { collegues } \\
\text { [107] }\end{array}$ & $\begin{array}{l}\text { The ATTACC, } \\
\text { ACTIV-4a, and } \\
\text { REMAP-CAP, } \\
\text { multiplatform } \\
\text { randomized } \\
\text { clinical trial }\end{array}$ & NEJM, 2021 & MPRCT & Critically ill & 1098 & $\begin{array}{l}\text { Standard } \\
\text { prophylactic- } \\
\text { dose versus } \\
\text { therapeutic- } \\
\text { dose heparin }\end{array}$ & $\begin{array}{l}\text { Organ support- } \\
\text { free days, death, } \\
\text { at } 21 \text { days }\end{array}$ & $\begin{array}{l}\text { No differences in } \\
\text { probability of survival to } \\
\text { hospital discharge with } \\
\text { reduced organ support in } \\
\text { the treatment group } \\
\text { Major bleeding occurred } \\
\text { more frequently in the } \\
\text { treatment group }\end{array}$ \\
\hline
\end{tabular}

MCRCT, multicenter randomized clinical trial; ICU, intensive care unit; LMWH, low molecular weight heparin; UFH, unfractionated heparin; VTE, venous thromboembolism; ATE, arterial thromboembolism; DIC, disseminated intravascular coagulation; ECMO, extracorporeal membrane oxygenation.

immunothrombotic processes. Other recently published randomized trials further evaluated the effect of prophylactic, intermediate, and therapeutic anticoagulation in hospitalized COVID-19 patients with yet inconclusive recommendations to the clinical setting (see Table 3) [111-114]. Currently, the American Society of Hematology (ASH) and International Society of Thrombosis and Haemostasis (ISTH) guidelines still recommend prophy- 
lactic anticoagulation in all COVID-19 patients (without evident VTE) until more evidence is available to perform otherwise [115]. Further investigation needs to evaluate the question whether therapeutic anticoagulation is indeed superior to prophylactic anticoagulation in reducing mortality in the critically ill and the noncritically ill COVID-19 patients in the light of adjusted treatment protocols [116].

\section{Post-Discharge Patients}

The ASH guideline panel does not recommend thromboprophylaxis to COVID-19 patients who are being discharged from the hospital without suspected or confirmed VTE or any other indication for anticoagulation (last updated in July 2021). In a study by Salisbury et al. [117], the rate of symptomatic VTE 42 days after discharge was $2.6 \%$. Even lower incidences were found in another study in which 4.8 per 1,000 discharges developed a VTE within 42 days after discharge [118]. Nevertheless, a recent study by Ramacciotti et al. [119] demonstrated improved clinical outcomes in extended thromboprophylaxis with rivaroxaban $10 \mathrm{mg} /$ day in patients at high risk for VTE after hospitalization due to COVID-19 infection. Further trials are required to evaluate the role of thromboprophylaxis post-discharge.

\section{Outpatients}

Current guidelines do not bring any recommendations regarding anticoagulation in outpatients with $\mathrm{CO}$ VID-19. Some of those patients are quite ill but can handle the disease at home without the need of extra medical support. This situation is increasingly observed lately as the younger population is infected by SARS-COV-2. As the virus' interaction with the host is heterogenous with many possible (parts of) immunothrombosis mechanisms interacting, it is imaginable that some of the younger patients may develop extensive pulmonary damage with a hypercoagulable state. Nevertheless, in a recent publication of symptomatic outpatients infected with SARS-COV-2 in which patients were randomly allocated to aspirin or apixaban compared to placebo, there was no reduction in rates of composite outcome observed (allcause mortality, symptomatic venous or arterial thromboembolism, myocardial infarction, stroke, or hospitalization for cardiovascular or pulmonary cause) [120]. However, the study was terminated early because of a lower than expected event rate ( $0 \%$ in the placebo group after 45 days of follow-up). Future larger studies have to further clarify whether there is need for thromboprophylaxis in the outpatient setting.

Coagulation Issues in COVID-19

\section{Other Anticoagulants and Antiplatelet Therapy in COVID-19}

DOACs are widely used as first choice therapy in DVT, pulmonary embolism, and atrial fibrillation. As DOACs interact with cytochrome $\mathrm{P} 450$ and/or P-glycoprotein, many drug-drug interactions may occur, resulting in a remarkable increase or decrease of their anticoagulant effect. Indeed, dexamethasone is an inducer (albeit a weak inducer) of CYP3A4, which may result in lower plasma concentrations of apixaban when used concomitantly for a certain time period [121]. Moreover, it is plausible that CYPs metabolic activity is downregulated during ARDS and other severely inflammatory states, resulting in an altered pharmacokinetic clearance and interaction. Therefore, one may recommend the avoidance of DOACs (especially apixaban and rivaroxaban) in admitted patients on dexamethasone until highquality evidence is becoming available [122]. A small study in patients showed that peak DOAC levels on dexamethasone were below the expected range in $33.3 \%$, of whom about two-thirds had also low levels without dexamethasone [123]. Scarce data are available on safety and efficacy of DOACs in COVID-19 patients. A study by Billett et al. [124] demonstrated a significant decrease in mortality with prophylactic doses of apixaban and enoxaparin, which was also apparent in the therapeutic dose of apixaban, but was not more beneficial. In our opinion, the use of DOACs should be case-based while keeping the patient's preference in mind as there is no contraindication to shortly combine dexamethasone with DOACs in noncritically ill patients, particularly when the expected discharge is soon.

At present, data on the effect of antiplatelet therapy in COVID-19 are scarce and no consensus guidelines are available regarding their use. From a pathophysiologic point of view, with platelet activation as key, it may be beneficial to inhibit platelet aggregation as they contribute to the process of microthrombosis in COVID-19. A retrospective study reported a decline of in-hospital mortality in patients who received aspirin within 1 week before or $24 \mathrm{~h}$ after admission [125]. Another retrospective study, using propensity score matching and multivariable regression, observed a lower mortality rate with in-hospital aspirin compared to no antiplatelet therapy [126]. Nevertheless, Berger et al. [127] demonstrated no benefit of the addition of a P2Y12 inhibitor to a therapeutic dose of heparin among noncritically ill COVID-19 patients regarding organ support-free days. Randomized trials are awaited to further elucidate the effect of antiplatelet therapy in COVID-19. 


\section{Future Treatment Considerations}

After demonstrating the bidirectional interactions between immune, endothelial, and coagulation systems and their hyperactivity in severe SARS-COV-2 infections that drives the heterogeneous clinical presentation between patients, it seems reasonable to consider a personalized therapy that more or less tackles those three components and restores homeostasis. As increasing evidence provides a critical role of NETosis in the pro-inflammatory and procoagulant state during severe COVID-19, we suggest that anti-NETs-targeted therapy alone or preferably in conjunction with anticoagulants may be more efficacious and may prevent disastrous thrombotic consequences in $\mathrm{CO}$ VID-19. Inhibiting NETosis may also be promising as a therapeutic option for VITT. Investigation of determinants of NETosis may reveal other potential targets for intervention. Another promising therapeutic strategy is perhaps through targeting the complement system by $\mathrm{C} 5$ blockade, which has demonstrated benefit in different kidney diseases such as C3 glomerulopathy and atypical hemolytic uremic syndrome [128]. Several trials are ongoing to investigate its benefits in severe SARS-COV-2 infection.

Regarding anticoagulant therapy, combining platelet inhibitors with DOACs or heparin may amplify the antithrombotic effect even more, when compared to solely increasing the dose of heparin. Future studies need to verify the optimal indication, timing, duration, and dose for anticoagulant therapy. In addition, fibrinolytic therapy has previously been reported in patients with severe COVID-19 and led to reduced mortality and marked improvement in oxygenation [129]. Further studies are warranted to determine whether tPA is worthy of consideration in clinical practice given the relatively high risk of catastrophic bleeding. In addition, the timing, dose, and combination with anticoagulants need to be further elucidated.

Our understanding of the physiologic role of tissue and circulating ACE2 is still very limited. Soon after the first case reports of COVID-19, ACE2 was detected as the bind- ing site for viral entry [130]. Investigating whether modulation of ACE2 expression would be effective in inhibiting further viral infection, and what the optimal timing of such an intervention might be, appears opportune. In fact, multiple trials are currently awaited with drugs that potentially bind or neutralize ACE2.

In conclusion, several treatment options are underway to tackle the hypercoagulable and hyperinflammatory state of COVID-19. This is of more importance as the current effective vaccination strategies appear thus far insufficient to dampen the disease burden and we still are in great need of more effective and safe anticoagulant and anti-inflammatory drug therapies in COVID-19 infection.

\section{Acknowledgments}

We thank miss Frederique Mullens for the professional illustrations. We thank Ali Hussein, MD, PhD, Department of Cellular Pathology in Cardiff and Vale University Health Board in the UK, for his language support.

\section{Conflict of Interest Statement}

T.A., M.M.G.M., and B.C.T.B. have no conflicts of interest to declare.

\section{Funding Sources}

Our COVID-19 research is funded by grants of the Netherlands Thrombosis Foundation (2020_A) and the Netherlands Organization for Health Research and Development (project number 10430012010004).

\section{Author Contributions}

T.A., M.M.G.M., B.C.T.B, and H.C. devised the main conceptual ideas and proof outline. T.A. took the lead in writing the review. All authors provided critical feedback and helped shape this work.

\section{References}

1 Osuchowski MF, Winkler MS, Skirecki T, Cajander S, Shankar-Hari M, Lachmann G, et al. The COVID-19 puzzle: deciphering pathophysiology and phenotypes of a new disease entity. Lancet Respir Med. 2021;9(6): $622-42$.

2 Mulder MMG, Brandts L, Brüggemann RAG, Koelmann M, Streng AS, Olie RH, et al. Serial markers of coagulation and inflammation and the occurrence of clinical pulmonary thromboembolism in mechanically ventilated patients with SARS-CoV-2 infection; the prospective Maastricht intensive care COVID cohort. Thromb J. 2021;19(1):35.

3 Yang W, Kandula S, Huynh M, Greene SK, Van Wye G, Li W, et al. Estimating the infection-fatality risk of SARS-CoV-2 in New York City during the spring 2020 pandemic wave: a model-based analysis. Lancet Infect Dis. 2021;21(2):203-12. 
4 Islam N, Shkolnikov VM, Acosta RJ, Klimkin I, Kawachi I, Irizarry RA, et al. Excess deaths associated with covid-19 pandemic in 2020: age and sex disaggregated time series analysis in 29 high income countries. BMJ. 2021;373: n1137.

5 Hulshof AM, Brüggemann RAG, Mulder MMG, van de Berg TW, Sels JEM, Olie RH, et al. Serial EXTEM, FIBTEM, and tPA rotational thromboelastometry observations in the maastricht intensive care COVID cohort-persistence of hypercoagulability and hypofibrinolysis despite anticoagulation. Front Cardiovasc Med. 2021;8:654174.

6 Campbell RA, Hisada Y, Denorme F, Grover SP, Bouck EG, Middleton EA, et al. Comparison of the coagulopathies associated with COVID-19 and sepsis. Res Pract Thromb Haemost. 2021;5(4):e12525.

7 Blot M, de Maistre E, Bourredjem A, Quenot JP, Nguyen M, Bouhemad B, et al. Specific features of the coagulopathy signature in severe COVID-19 pneumonia. Front Med. 2021;8:675191.

8 Han H, Yang L, Liu R, Liu F, Wu KL, Li J, et al. Prominent changes in blood coagulation of patients with SARS-CoV-2 infection. Clin Chem Lab Med. 2020;58(7):1116-20.

9 Busch MH, Timmermans SA, Nagy M, Visser M, Huckriede J, Aendekerk JP, et al. Neutrophils and contact activation of coagulation as potential drivers of COVID-19. Circulation. 2020;142(18):1787-90.

10 Zhu N, Zhang D, Wang W, Li X, Yang B, Song J, et al. A novel coronavirus from patients with pneumonia in China, 2019. N Engl J Med. 2020;382(8):727-33.

11 Coronaviridae Study Group of the International Committee on Taxonomy of, Viruses. The species severe acute respiratory syndrome-related coronavirus: classifying 2019$\mathrm{nCoV}$ and naming it SARS-CoV-2. Nat Microbiol. 2020;5(4):536-44.

12 Wiersinga WJ, Rhodes A, Cheng AC, Peacock SJ, Prescott HC. Pathophysiology, transmission, diagnosis, and treatment of coronavirus disease 2019 (COVID-19): a review. JAMA. 2020;324(8):782-93.

13 Kuiken T, Fouchier RA, Schutten M, Rimmelzwaan GF, van Amerongen G, van Riel D, et al. Newly discovered coronavirus as the primary cause of severe acute respiratory syndrome. Lancet. 2003;362(9380):263-70.

14 Zaki AM, van Boheemen S, Bestebroer TM, Osterhaus AD, Fouchier RA. Isolation of a novel coronavirus from a man with pneumonia in Saudi Arabia. N Engl J Med. 2012; 367(19):1814-20.

15 Tay MZ, Poh CM, Rénia L, MacAry PA, Ng LFP. The trinity of COVID-19: immunity, inflammation and intervention. Nat Rev Immunol. 2020;20(6):363-74.

16 Choudhary S, Sharma K, Singh H, Silakari O. The interplay between inflammatory pathways and COVID-19: a critical review on pathogenesis and therapeutic options. Microb Pathog. 2021;150:104673.
17 Chen Y, Guo Y, Pan Y, Zhao ZJ. Structure analysis of the receptor binding of 2019nCoV. Biochem Biophys Res Commun. 2020; 525(1):135-40.

18 Bunyavanich S, Do A, Vicencio A. Nasal gene expression of angiotensin-converting enzyme 2 in children and adults. JAMA. 2020;323(23): 2427-9.

19 Li X, Geng M, Peng Y, Meng L, Lu S. Molecular immune pathogenesis and diagnosis of COVID-19. J Pharm Anal. 2020;10(2):102-8.

20 Bels JLM, van Kuijk SMJ, Ghossein-Doha C, Tijssen FH, van Gassel RJJ, Tas J, et al. Decreased serial scores of severe organ failure assessments are associated with survival in mechanically ventilated patients; the prospective maastricht intensive care COVID cohort. J Crit Care. 2021;62:38-45.

21 Mehta P, McAuley DF, Brown M, Sanchez E, Tattersall RS, Manson JJ, et al. COVID-19: consider cytokine storm syndromes and immunosuppression. Lancet. 2020;395(10229): $1033-4$.

22 Kox M, Waalders NJB, Kooistra EJ, Gerretsen J, Pickkers P. Cytokine levels in critically Ill patients with COVID-19 and other conditions. JAMA. 2020;324(15):1565-7.

23 Bouck EG, Denorme F, Holle LA, Middelton EA, Blair AM, de Laat B, et al. COVID-19 and sepsis are associated with different abnormalities in plasma procoagulant and fibrinolytic activity. Arterioscler Thromb Vasc Biol. 2021; 41(1):401-14

24 Zhang C, Shen L, Le KJ, Pan MM, Kong LC, $\mathrm{Gu} \mathrm{ZC}$, et al. Incidence of venous thromboembolism in hospitalized coronavirus disease 2019 patients: a systematic review and metaanalysis. Front Cardiovasc Med. 2020;7:151.

25 Tufano A, Rendina D, Abate V, Casoria A, Marra A, Buonanno P, et al. Venous thromboembolism in COVID-19 compared to nonCOVID-19 cohorts: a systematic review with meta-analysis. J Clin Med. 2021. 10(21.4925.

26 Belani P, Schefflein J, Kihira S, Rigney B, Delman BN, Mahmoudi K, et al. COVID-19 is an independent risk factor for acute ischemic stroke. AJNR Am J Neuroradiol. 2020;41(8): 1361-4.

27 Oxley TJ, Mocco J, Majidi S, Kellner CP, Shoirah H, Singh IP, et al. Large-vessel stroke as a presenting feature of covid-19 in the young. $\mathrm{N}$ Engl J Med. 2020;382(20):e60.

28 Aird WC. Endothelium and haemostasis. Hamostaseologie. 2015;35(1):11-6.

29 Aird WC. Phenotypic heterogeneity of the endothelium: structure, function, and mechanisms. Circ Res. 2007;100(2):158-73.

30 Aird WC. Phenotypic heterogeneity of the endothelium: II. Representative vascular beds. Circ Res. 2007;100(2):174-90.

31 Levi M, ten Cate H, van der Poll T. Endothelium: interface between coagulation and inflammation. Crit Care Med. 2002;30(5 Suppl 1):S220-4.

32 Pons S, Arnaud M, Loiselle M, Arrii E, Azoulay E, Zafrani L. Immune consequences of endothelial cells' activation and dysfunction during sepsis. Crit Care Clin. 2020;36(2):40113.

33 Goshua G, Pine AB, Meizlish ML, Chang CH, Zhang H, Bahel P, et al. Endotheliopathy in COVID-19-associated coagulopathy: evidence from a single-centre, cross-sectional study. Lancet Haematol. 2020;7(8):e575e582.

34 Giamarellos-Bourboulis EJ, Netea MG, Rovina N, Akinosoglou K, Antoniadou A, Antonakos $\mathrm{N}$, et al. Complex immune dysregulation in COVID-19 patients with severe respiratory failure. Cell Host Microbe. 2020;27(6):9921000 e3.

35 Ackermann M, Verleden SE, Kuehnel M, Haverich A, Welte T, Laenger F, et al. Pulmonary vascular endothelialitis, thrombosis, and angiogenesis in covid-19. N Engl J Med. 2020; 383(2):120-8.

36 Thacker VV, Sharma K, Dhar N, Mancini GF, Sordet-Dessimoz J, McKinney JD. Rapid endotheliitis and vascular damage characterize SARS-CoV-2 infection in a human lung-on-chip model. EMBO Rep. 2021; 22(6): e52744.

37 D'Elia RV, Harrison K, Oyston PC, Lukaszewski RA, Clark GC. Targeting the "cytokine storm" for therapeutic benefit. Clin Vaccine Immunol. 2013;20(3):319-27.

38 Us D. Cytokine storm in avian influenza. Mikrobiyol Bul. 2008;42(2):365-80.

39 Perrone LA Plowden JK, García-Sastre A, Katz JM, Tumpey TM. H5N1 and 1918 pandemic influenza virus infection results in early and excessive infiltration of macrophages and neutrophils in the lungs of mice. PLoS Pathog. 2008;4(8):e1000115.

40 Wynants L, Van Calster B, Collins GS, Riley RD, Heinze G, Schuit E, et al. Prediction models for diagnosis and prognosis of covid-19: systematic review and critical appraisal. BMJ. 2020;369:m1328.

41 Elsoukkary SS, Mostyka M, Dillard A, Berman DR, Ma LX, Chadburn A, et al. Autopsy findings in 32 patients with COVID-19: a single-institution experience. Pathobiology. 2021;88(1):56-68.

42 Bonaventura A, Vecchié A, Dagna L, Martinod K, Dixon DL, Van Tassell BW, et al. Endothelial dysfunction and immunothrombosis as key pathogenic mechanisms in COVID-19. Nat Rev Immunol. 2021;21(5): 319-29.

43 Gillot C, Favresse J, Mullier F, Lecompte T, Dogné JM, Douxfils J. NETosis and the immune system in COVID-19: mechanisms and potential treatments. Front Pharmacol. 2021; 12:708302.

44 Zhang D, Chen G, Manwani D, Mortha A, Xu C, Faith JJ, et al. Neutrophil ageing is regulated by the microbiome. Nature. 2015; 525(7570):528-32.

45 Martinod K, Chen G, Manwani D, Mortha A, Xu C, Faith JJ, et al. PAD4-deficiency does not affect bacteremia in polymicrobial sepsis and ameliorates endotoxemic shock. Blood. 2015; 125(12):1948-56. 
46 Sollberger G, Tilley DO, Zychlinsky A. Neutrophil extracellular traps: the biology of chromatin externalization. Dev Cell. 2018; 44(5):542-53.

47 Fuchs TA, Brill A, Duerschmied D, Schatzberg D, Monestier M, Myers DD, et al. Extracellular DNA traps promote thrombosis. Proc Natl Acad Sci U S A. 2010;107(36):15880-5.

48 Noubouossie DF, Whelihan MF, Yu YB, Sparkenbaugh E, Pawlinski R, Monroe DM, et al. In vitro activation of coagulation by human neutrophil DNA and histone proteins but not neutrophil extracellular traps. Blood. 2017;129(8):1021-9.

49 McDonald B, Davis RP, Kim SJ, Tse M, Esmon CT, Kolaczkowska E, et al. Platelets and neutrophil extracellular traps collaborate to promote intravascular coagulation during sepsis in mice. Blood. 2017;129(10):1357-67.

50 Colling ME, Tourdot BE, Kanthi Y. Inflammation, infection and venous thromboembolism. Circ Res. 2021;128(12):2017-36.

51 Grommes J, Alard JE, Drechsler M, Wantha S, Mörgelin M, Kuebler WM, et al. Disruption of platelet-derived chemokine heteromers prevents neutrophil extravasation in acute lung injury. Am J Respir Crit Care Med. 2012; 185(6):628-36

52 Schonrich G, Raftery MJ. Neutrophil extracellular traps go viral. Front Immunol. 2016; $7: 366$.

53 Zuo Y, Yalavarthi S, Shi H, Gockman K, Zuo M, Madison JA, et al. Neutrophil extracellular traps (NETs) as markers of disease severity in COVID-19. medRxiv. 2020.

54 Santiesteban-Lores LE, Cabrera-Crespo J, Carvalho E. A double edged-sword: the complement system during SARS-CoV-2 infection. Life Sci. 2021;272:119245.

55 Visser M, Heitmeier S, Ten Cate H, Spronk $\mathrm{HMH}$. Role of factor XIa and plasma kallikrein in arterial and venous thrombosis. Thromb Haemost. 2020;120(6):883-993.

56 Magro C, Mulvey JJ, Berlin D, Nuovo G, Salvatore S, Harp J, et al. Complement associated microvascular injury and thrombosis in the pathogenesis of severe COVID-19 infection: a report of five cases. Transl Res. 2020;220: $1-13$.

57 Lindemann S, Tolley ND, Dixon DA, McIntyre TM, Prescott SM, Zimmerman GA, et al. Activated platelets mediate inflammatory signaling by regulated interleukin 1beta synthesis. J Cell Biol. 2001;154(3):485-90.

58 Manne BK, Denorme F, Middleton EA, Portier I, Rowley JW, Stubben C, et al. Platelet gene expression and function in patients with COVID-19. Blood. 2020;136(11):1317-29.

59 Nevzorova TA, Mordakhanova ER, Daminova AG, Ponomareva AA, Andrianova IA, Le Minh G, et al. Platelet factor 4-containing immune complexes induce platelet activation followed by calpain-dependent platelet death. Cell Death Discov. 2019;5:106.

60 Zhu W, Schrottmaier WC, Salzmann M, Rayes J. SARS-CoV-2 receptor binding domain-specific antibodies activate platelets with features resembling the pathogenic antibodies in heparin-induced thrombocytopenia. Res Sq. 2021.

61 Assinger A, Schrottmaier WC, Salzmann M, Rayes J. Platelets in sepsis: an update on experimental models and clinical data. Front Immunol. 2019;10:1687.

62 Baker SK, Strickland S. A critical role for plasminogen in inflammation. J Exp Med. 2020; 217(4).

63 Liu ZH, Wei R, Wu YP, Lisman T, Wang ZX, Han JJ, et al. Elevated plasma tissue-type plasminogen activator (t-PA) and soluble thrombomodulin in patients suffering from severe acute respiratory syndrome (SARS) as a possible index for prognosis and treatment strategy. Biomed Environ Sci. 2005;18(4):260-4.

64 Zuniga M, Gomes C, Carsons SE, Bender MT, Cotzia P, Miao QR, et al. Autoimmunity to annexin A2 predicts mortality among hospitalised COVID-19 patients. Eur Respir J;2021; 58(4):2100918.

65 Goldman M, Hermans C. Thrombotic thrombocytopenia associated with COVID-19 infection or vaccination: possible paths to platelet factor 4 autoimmunity. PLoS Med. 2021; 18(5):e1003648.

66 Dagan N, Barda N, Kepten E, Miron O, Perchik S, Katz MA, et al. BNT162b2 mRNA Covid-19 vaccine in a nationwide mass vaccination setting. N Engl J Med. 2021;384(15): 1412-23.

67 Greinacher A, Thiele T, Warkentin TE, Weisser K, Kyrle PA, Eichinger S. Thrombotic hrombocytopenia after ChAdOx1 nCov-19 vaccination. N Engl J Med. 2021;384(22):2092-101.

68 Sangli S, Virani A, Cheronis N, Vannatter B, Minich C, Noronha S, et al. Thrombosis with thrombocytopenia after the messenger RNA1273 vaccine. Ann Intern Med. 2021;174(10): $1480-2$.

69 Cines DB, Bussel JB. SARS-CoV-2 vaccineinduced immune thrombotic thrombocytopenia. N Engl J Med. 2021;384(23):2254-6.

70 Pavord S, Scully M, Hunt BJ, Lester W, Bagot $\mathrm{C}$, Craven $\mathrm{B}$, et al. Clinical features of vaccineinduced immune thrombocytopenia and thrombosis. N Engl J Med. 2021;385(18): $1680-9$.

71 Scully M, Singh D, Lown R, Poles A, Solomon $\mathrm{T}$, Levi $\mathrm{M}$, et al. Pathologic antibodies to platelet factor 4 after ChAdOx $1 \mathrm{nCoV}-19 \mathrm{vac}-$ cination. N Engl J Med. 2021;384(23):220211.

72 Perdomo J, Leung HHL, Ahmadi Z, Yan F, Chong JJH, Passam FH, et al. Neutrophil activation and NETosis are the major drivers of thrombosis in heparin-induced thrombocytopenia. Nat Commun. 2019;10(1):1322.

73 Greinacher A, Selleng K, Palankar R, Wesche J, Handtke S, Wolff $\mathrm{M}$, et al. Insights in ChAdOx1 nCov-19 vaccine-induced immune thrombotic thrombocytopenia (VITT). Blood. 2021;138(22):2256-68

74 Fraser DD, Patterson EK, Slessarev M, Gill SE, Martin C, Daley M, et al. Endothelial injury and glycocalyx degradation in critically Ill coronavirus disease 2019 patients: implications for microvascular platelet aggregation. Crit Care Explor. 2020;2(9):e0194.

75 Greinacher A, Langer F, Makris M, Pai M, Pavord S, Tran H, et al. Vaccine-induced immune thrombotic thrombocytopenia (VITT): update on diagnosis and management considering different resources. J Thromb Haemost. 2021;20(1):149-56.

76 Berger JS, Kunichoff D, Adhikari S, Ahuja T, Amoroso N, Aphinyanaphongs Y, et al. Prevalence and outcomes of D-dimer elevation in hospitalized patients with COVID-19. Arterioscler Thromb Vasc Biol. 2020;40(10):2539-47.

77 Zhou F, Yu T, Du R, Fan G, Liu Y, Liu Z, et al Clinical course and risk factors for mortality of adult inpatients with COVID-19 in Wuhan, China: a Retrospective Cohort Study. Lancet. 2020;395(10229):1054-62.

78 Tang N, Li D, Wang X, Sun Z. Abnormal coagulation parameters are associated with poor prognosis in patients with novel coronavirus pneumonia. J Thromb Haemost. 2020;18(4): 844-7.

79 Canzano P, Brambilla M, Porro B, Cosentino N, Tortorici E, Vicini S, et al. Platelet and endothelial activation as potential mechanisms behind the thrombotic complications of COVID-19 patients. JACC Basic Transl Sci. 2021; 6(3):202-18.

80 Raadsen M, Du Toit J, Langerak T, van Bussel B, van Gorp E, Goeijenbier M. Thrombocytopenia in virus infections. J Clin Med. 2021; 10(4):99.

81 Taus F, Salvagno G, Canè S, Fava C, Mazzaferri F, Carrara E, et al. Platelets promote thromboinflammation in SARS-CoV-2 pneumonia. Arterioscler Thromb Vasc Biol. 2020; 40(12):2975-89.

82 Campo G, Contoli M, Fogagnolo A, Vieceli Dalla Sega F, Zucchetti O, Ronzoni L, et al. Over time relationship between platelet reactivity, myocardial injury and mortality in patients with SARS-CoV-2-associated respiratory failure. Platelets. 2021;32(4):560-7.

83 Yatim N, Boussier J, Chocron R, Hadjadj J, Philippe A, Gendron N, et al. Platelet activation in critically ill COVID-19 patients. Ann Intensive Care. 2021;11(1):113.

84 Karsli E, Sabirli R, Altintas E, Canacik O, Sabirli GT, Kaymaz B, et al. Soluble P-selectin as a potential diagnostic and prognostic biomarker for COVID-19 disease: a case-control study. Life Sci. 2021;277:119634.

85 Comer SP, Cullivan S., Szklanna PB, Weiss L, Cullen S, Kelliher S, et al. COVID-19 induces a hyperactive phenotype in circulating platelets. PLoS Biol. 2021;19(2):e3001109.

86 Thachil J, Lisman T. Pulmonary megakaryocytes in coronavirus disease 2019 (COVID-19): roles in thrombi and fibrosis. Semin Thromb Hemost. 2020;46(7):831-4.

87 Wada H, Thachil J, Di Nisio M, Mathew P, Kurosawa S, Gando S, et al. Guidance for diagnosis and treatment of DIC from harmonization of the recommendations from three guidelines. J Thromb Haemost. 2013. 
88 Coccheri S. COVID-19: the crucial role of blood coagulation and fibrinolysis. Intern Emerg Med. 2020;15(8):1369-73.

89 Devreese KMJ. COVID-19-related laboratory coagulation findings. Int $\mathrm{J} \mathrm{Lab} \mathrm{Hematol.}$ 2021;43(Suppl 1):36-42.

90 Binder NB, Hurlen M, Arnesen H. Clinical use of thrombin generation assays. J Thromb Haemost. 2021;2(5):726-30.

91 Campello E, Bulato C, Spiezia L, Boscolo A, Poletto F, Cola M, et al. Thrombin generation in patients with COVID-19 with and without thromboprophylaxis. Clin Chem Lab Med. 2021;59(7):1323-30.

92 de la Morena-Barrio ME, Bravo-Pérez C, Miñano A, de la Morena-Barrio B, Fernandez-Perez MP, Berna E, et al. Prognostic value of thrombin generation parameters in hospitalized COVID-19 patients. Sci Rep. 2021;11(1):7792.

93 van de Berg TW, Hulshof AM, Nagy M, van Oerle R, Sels JW, van Bussel B, et al. Suggestions for global coagulation assays for the assessment of COVID-19 associated hypercoagulability. Thromb Res. 2021;201:84-9.

94 Panigada M, Bottino N, Tagliabue P, Grasselli G, Novembrino C, Chantarangkul V, et al. Hypercoagulability of COVID-19 patients in intensive care unit: a report of thromboelastography findings and other parameters of hemostasis. J Thromb Haemost. 2020;18(7):1738-42.

95 Bareille M, Hardy M, Douxfils J, Roullet S, Lasne D, Levy JH, et al. Viscoelastometric testing to assess hemostasis of COVID-19: a systematic review. J Clin Med. 2021;10(8): 1740.

96 Hulshof AM, Braeken DCW, Ghossein-Doha C, van Santen S, Sels JEM, Kuiper GJAJM, et al. Hemostasis and fibrinolysis in COVID-19 survivors 6 months after intensive care unit discharge. Res Pract Thromb Haemost. 2021;5(6):e12579.

97 Meizoso JP, Moore HB, Moore EE. Fibrinolysis shutdown in COVID-19: clinical manifestations, molecular mechanisms, and therapeutic implications. J Am Coll Surg. 2021; 232(6):995-1003.

98 Ranucci M, Sitzia C, Baryshnikova E, Di Dedda U, Cardani R, Martelli F, et al. Covid19-associated coagulopathy: biomarkers of thrombin generation and fibrinolysis leading the outcome. J Clin Med. 2020;9(11): 3487.

99 Tang N, Bai H, Chen X, Gong J, Li D, Sun Z. Anticoagulant treatment is associated with decreased mortality in severe coronavirus disease 2019 patients with coagulopathy. J Thromb Haemost. 2020;18(5):1094-9.

100 Vaughn VM, Yost M, Abshire C, Flanders SA, Paje D, Grant $\mathrm{P}$, et al. Trends in venous thromboembolism anticoagulation in patients hospitalized with COVID-19. JAMA Netw Open. 2021;4(6):e2111788.

101 Paranjpe I, Fuster V, Lala A, Russak AJ, Glicksberg BS, Levin MA, et al. Association of treatment dose anticoagulation with in- hospital survival among hospitalized patients with COVID-19. J Am Coll Cardiol. 2020;76(1):122-4.

102 Gozzo L, Viale P, Longo L, Vitale DC, Drago F. The potential role of heparin in patients with COVID-19: beyond the anticoagulant effect. A review. Front Pharmacol. 2020;11: 1307.

103 Mycroft-West CJ, Su D, Pagani I, Rudd TR, Elli S, Gandhi NS, et al. Heparin inhibits cellular invasion by SARS-CoV-2: structural dependence of the interaction of the spike S1 receptor-binding domain with heparin. Thromb Haemost. 2020;120(12):1700-15.

104 Piazza G, Morrow DA. Diagnosis, management, and pathophysiology of arterial and venous trombosis in COVID-19. JAMA. 2020;324(24):2548-9.

105 Levy JH, Connors JM. Heparin resistance: clinical perspectives and management strategies. N Engl J Med. 2021;385(9):826-32.

106 ATTACC Investigators; ACTIV-4a Investigators; REMAP-CAP Investigators; Lawler PR, Goligher EC, Berger JS, Neal MD, et al. Therapeutic anticoagulation with heparin in noncritically Ill patients with covid-19. N Engl J Med. 2021;385(9):790-802.

107 REMAP-CAP Investigators; ACTIV-4a Investigators; ATTACC Investigators; Goligher EC, Bradbur CA, McVerry BJ, et al. Therapeutic anticoagulation with heparin in critically Ill patients with Covid-19. N Engl J Med. 2021;385(9):777-89.

108 Mesotten D, Meijs DAM, van Bussel BCT, Stessel B, Mehagnoul-Schipper J, Hana A, et al. Differences and similarities among coronavirus disease 2019 patients treated in seven ICUs in three countries within one region: an Observational Cohort Study. Crit Care Med. 2021.

109 Levy JH, Sniecinski RM, Welsby IJ, Levi M. Antithrombin: anti-inflammatory properties and clinical applications. Thromb Haemost. 2016;115(4):712-28.

110 WHO Rapid Evidence Appraisal for COVID-19 Therapies (REACT) Working Group, Shankar-Hari M, Vale CL, Godolphin PJ, Fisher D, Higgins JPT, et al. Association between administration of IL-6 antagonists and mortality among patients hospitalized for COVID-19: a meta-analysis. JAMA. 2021;326(6):499-518.

111 Spyropoulos AC, Goldin M, Giannis D, Diab W, Wang J, Khanijo S, et al. Efficacy and safety of therapeutic-dose heparin vs standard prophylactic or intermediate-dose heparins for thromboprophylaxis in high-risk hospitalized patients with COVID-19: the HEP-COVID randomized clinical trial. JAMA Intern Med. 2021;181(12):1612-20.

112 Perepu US, Chambers I, Wahab A, Ten Eyck P, Wu C, Dayal S, Sutamtewagul G, et al. Standard prophylactic versus intermediate dose enoxaparin in adults with severe $\mathrm{CO}$ VID-19: a multi-center, open-label, randomized controlled trial. J Thromb Haemost. 2021;19(9):2225-34.
113 Lopes RD, de Barros E Silva PGM, Furtado RHM, Macedo AVS, Ramacciotti E, Damini LP, et al. Randomized clinical trial to evaluate a routine full anticoagulation strategy in patients with coronavirus infection (SARSCoV2) admitted to hospital: rationale and design of the ACTION (antiCoagulaTlon cOroNavirus)-coalition IV trial. Am Heart J. 2021;238:1-11.

114 INSPIRATION Investigators, Sadeghipour P, Talasaz AH, Rashidi F, Sharif-Kashani B, Beigmohammadi MT, et al. Effect of intermediate-dose vs standard-dose prophylactic anticoagulation on thrombotic events, extracorporeal membrane oxygenation treatment, or mortality among patients with $\mathrm{CO}$ VID-19 admitted to the intensive care unit: the INSPIRATION randomized clinical trial. JAMA. 2021;325(16):1620-30.

115 Cuker A, Tseng EK, Nieuwlaat R, Angchaisuksiri P, Blair C, Dane K, et al. American Society of Hematology living guidelines on the use of anticoagulation for thromboprophylaxis in patients with COVID-19: May 2021 update on the use of intermediateintensity anticoagulation in critically ill patients. Blood Adv. 2021;5(20):3951-9.

116 Ten Cate H. Surviving Covid-19 with Heparin? N Engl J Med. 2021;385(9):845-6.

117 Salisbury R, Iotchkova V, Jaafar S, Morton J, Sangha G, Shah A, et al. Incidence of symptomatic, image-confirmed venous thromboembolism following hospitalization for COVID-19 with 90-day follow-up. Blood Adv. 2020;4(24):6230-9.

118 Roberts LN, Whyte MB, Georgiou L, Giron G, Czuprynska J, Rea C, et al. Postdischarge venous thromboembolism following hospital admission with COVID-19. Blood. 2020 136(11):1347-50.

119 Ramacciotti E, Barile Agati L, Calderaro D, Aguiar VCR, Spyropoulos AC, de Oliveira CCC, et al. Rivaroxaban versus no anticoagulation for post-discharge thromboprophylaxis after hospitalisation for COVID-19 (MICHELLE): an open-label, multicentre, randomised, controlled trial. Lancet. 2022; 399(10319):50-9.

120 Connors JM, Brooks MM, Sciurba FC, Krishnan JA, Bledsoe JR, Kindzelski A, et al Effect of antithrombotic therapy on clinical outcomes in outpatients with clinically stable symptomatic COVID-19: the ACTIV-4B randomized clinical trial. JAMA. 2021; 326(17):1703-12.

121 Schutgens RE. DOAC in COVID-19: yes or no? Hemasphere. 2021;5(1):e526.

122 Smythe MA, Burns C, Liu Q, Garwood C. Potential dexamethasone-direct oral anticoagulant drug interaction: is this a concern in COVID? Ann Pharmacother. 2021;56(3): $319-29$.

123 Potere N, Candeloro M, Porreca E, Marinari S, Federici C, Auciello R, et al. Direct oral anticoagulant plasma levels in hospitalized COVID-19 patients treated with dexamethasone. J Thromb Thrombolysis. 2021;1-6. 
124 Billett HH, Reyes-Gil M, Szymanski J, Ikemura K, Stahl LR, Lo Y, et al. Anticoagulation in COVID-19: effect of enoxaparin, heparin, and apixaban on mortality. Thromb Haemost. 2020;120(12):1691-9.

125 Chow JH, Khanna AK, Kethireddy S, Yamane D, Levine A, Jackson AM, et al. Aspirin use is associated with decreased mechanical ventilation, intensive care unit admission, and in-hospital mortality in hospitalized patients with coronavirus disease 2019. Anesth Analg. 2021;132(4):93041

126 Meizlish ML, Goshua G, Liu Y, Fine R, Amin $\mathrm{K}$, Chang $\mathrm{E}$, et al. Intermediate-dose anticoagulation, aspirin, and in-hospital mortality in COVID-19: A propensity score-matched analysis. Am J Hematol. 2021;96(4):471-9.

127 Berger JS, Kornblith LZ, Gong MN, Reynolds HR, Cushman M, Cheng Y, et al. Effect of P2Y12 inhibitors on survival free of organ support among non-critically Ill hospitalized patients with COVID-19: a randomized clinical trial. JAMA. 2022;327(3):22736.

128 Perico L, Benigni A, Casiraghi F, Ng LFP, Renia L, Remuzzi G. Immunity, endothelial injury and complement-induced coagulopathy in COVID-19. Nat Rev Nephrol. 2021; 17(1):46-64.

129 Wang J, Hajizadeh N, Moore EE, McIntyre RC, Moore PK, Veress LA, et al. Tissue plas- minogen activator (tPA) treatment for $\mathrm{CO}$ VID-19 associated acute respiratory distress syndrome (ARDS): a case series. J Thromb Haemost. 2020;18(7):1752-5.

130 Bhalla V, Blish CA, South AM. A historical perspective on ACE2 in the COVID-19 era. J Hum Hypertens. 2021;35(10):935-9.

131 Sholzberg M, Tang GH, Rahhal H, AlHamzah M, Kreuziger LB, Áinle FN, et al.; RAPID trial investigators. Effectiveness of therapeutic heparin versus prophylactic heparin on death, mechanical ventilation, or intensive care unit admission in moderately ill patients with covid-19 admitted to hospital: RAPID randomised clinical trial. BMJ. 2021 Oct 14;375:n2400 